\title{
Original paper \\ Mineral inclusions in pyrope from garnet peridotites, Kolín area, central Czech Republic
}

\author{
Stanislav VRÁNA
}

Czech Geological Survey, Klárov 3, 11821 Prague 1, Czech Republic; stanislav.vrana@geology.cz

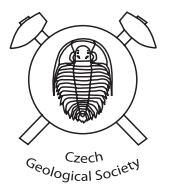

\begin{abstract}
Mineral inclusions were studied with emphasis on the relatively abundant acicular, preferentially oriented rutile in pyrope from the Kolín area. In contrast, rutile inclusions are rare or absent at two other, currently exploited pyrope deposits in northern Bohemia (Podsedice and Vestřev). The aim was also to obtain the first analytical information on variety of other mineral inclusions, some of which were previously indicated in the literature based on qualitative gemmological observation. Host garnet composition shows limited variation with Prp 67.9-71.6, Alm 13.3-18.9, Grs 2.0-7.5 and Uvr 2.6-9.6 mol. \%. Electron microprobe study resulted in identification of the following mineral inclusions in pyrope: rutile, magnesian ilmenite, olivine, magnesite, enstatite, pargasite, phlogopite, barian phlogopite, spinel, and a probable crichtonite-series? mineral. Apatite, Ni-sulphide and chalcopyrite were identified based on qualitative spectra. Published $\mathrm{Sm}-\mathrm{Nd}$ mineral ages point to the presence of two age groups of the Variscan garnet peridotites in the Moldanubian Zone and adjacent units in the Bohemian Massif, i.e. the "neo-Variscan" ( $339 \mathrm{Ma})$, and the "palaeo-Variscan" (370-377 Ma). In the Kolín area, the Bečváry body was dated at $377 \pm 20 \mathrm{Ma}$. This raises a question, whether the "palaeo-Variscan" garnet peridotites of the Kolín area carry some mineralogical record of protracted annealing or repeated heating, which may have occurred between the two Variscan events. Information from garnet inclusions does not indicate for the Kolín peridotites a history of recycling of older peridotites with pre-Variscan crustal residence. Average $\mathrm{TiO}_{2}$ contents in pyrope from the Kolín area $\left(0.37\right.$ wt. \%) compare with 0.46 wt. \% $\mathrm{TiO}_{2}$ in Vestřev pyropes and 0.52 wt. \% TiO in Podsedice pyropes (northern Bohemia). This suggests that the relatively low Ti content in Kolín pyrope may be in part due to Ti unmixing in the form of oriented acicular rutile. The data from the present study point to the potential of mineralogical comparative studies on peridotites from individual HP units of the Bohemian Massif.
\end{abstract}

Keywords: pyrope, mineral inclusions, garnet peridotite, Kutná Hora Crystalline Unit, Bohemian Massif

Received: 10 December 2007; accepted 14 March 2008; handling editor: J. Kotková

\section{Introduction}

Modern studies of garnet peridotites (lherzolites) in the Bohemian Massif brought important geochronological, geochemical and geothermobarometric data sets reviewed by Becker (1997), Schmädicke and Evans (1997) and Medaris et al. $(2005,2006)$. Considerable complexity follows from definition of three distinct compositional types of garnet peridotites (Medaris et al. 2005). For simplicity, somewhat variable olivine-rich pyropic ultramafic rocks, often with lherzolite composition, are designated as garnet peridotite in the following text.

Less attention so far has been paid to comparative mineralogical study of minor phases or mineral inclusions in pyrope of garnet peridotites from individual HP units. Mineral inclusions in pyrope can be classified as (a) primary inclusions, i.e. grains, which existed at the time of garnet growth and were passively enclosed by garnet, and (b) unmixed minerals, i.e. phases crystallized in the host garnet from elements expelled from garnet structure; they involve rutile and magnesian ilmenite typically showing regular orientation. The situation with $\mathrm{TiO}_{2}$ phases is somewhat complicated by discovery of the natural occurrence of a high-pressure $\mathrm{TiO}_{2}$ polymorph, isostructural with $\alpha \mathrm{PbO}_{2}$ (Hwang et al. 2000), stable in a range of 50-90 kbar (Frost et al. 2004). In the absence of structural information, acicular $\mathrm{TiO}_{2}$ in the studied pyrope is considered as rutile.

Běhal et al. (2000) and Hyršl (2002) noted the presence of abundant mineral inclusions in pyrope as a characteristic feature for localities near Kolín (Figs 1,2), which is in contrast to the rarity or absence of inclusions at some classic, currently exploited localities such as Podsedice and Vestř̌ev in northern Bohemia (Fig. 1). Hyršl (2002) published gemmological observations using optical microscope on 15 faceted pieces of pyrope from the vicinity of Kolín. The following inclusions were described: (a) framework of light-coloured acicular rutile and similar opaque particles, (b) colourless to greenish rounded inclusions, often with adhering minute opaque crystal, (c) three types of minute colourless inclusions, rounded, angular, or prismatic, (d) minute opaque inclusions, and (e) minute colourless inclusions accompanied by local fractures in the host garnet. Some large polished pyrope stones with rutile inclusions, decorating historical jewelery objects, can be possibly traced to localities near Kolín (Hyršl 2001). 


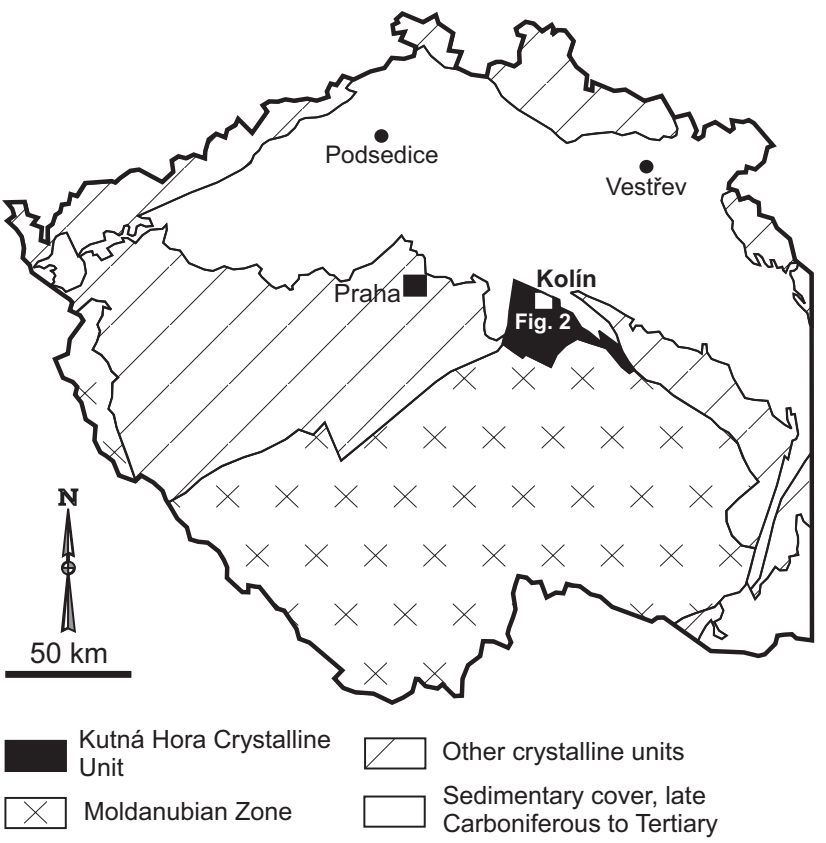

Fig. 1 Location of the Kolín area, Podsedice and Vestřev occurrences in the Bohemian Massif.

The present study aims at obtaining quantitative mineralogical data on mineral inclusions in pyrope derived from garnet peridotites of the Kolín area in central Bohemia and at characterizing their relation to garnet peridotites in some other units of the Bohemian Massif. Critically assessed is also the possibility that inclusions in pyrope are indicative of a previous crustal history, as is the case of some occurrences in Norway and China (Brueckner and Medaris 2000).

\section{Geological setting}

In the Czech part of the Bohemian Massif garnet peridotites occur mainly in the Gföhl Nappe of the Moldanubian Zone and the Kutná Hora Crystalline Unit (KHCU) (Dallmeyer et al. 1995). Regional distribution of abundant garnet peridotites, garnet clinopyroxenites and eclogites in the Moldanubian Zone is shown in a sketch map (Vrána et al. 1995, fig. 1). However, in the opinion of the present author, KHCU should not be considered as a part of the Moldanubian Zone, as it shows some important differences. The distinctive character of KHCU, as compared to the Moldanubian complex, was first formulated by Koutek (1933). Although, later on, opinion on relation of these units varied (see review in Synek and Oliveriová 1993), new unpublished geochemical and petrological information indicates that KHCU (including the Běstvina Granulite) and the Svratka Crystalline Unit further east can be probably correlated with the Orlica-Śnieżnik

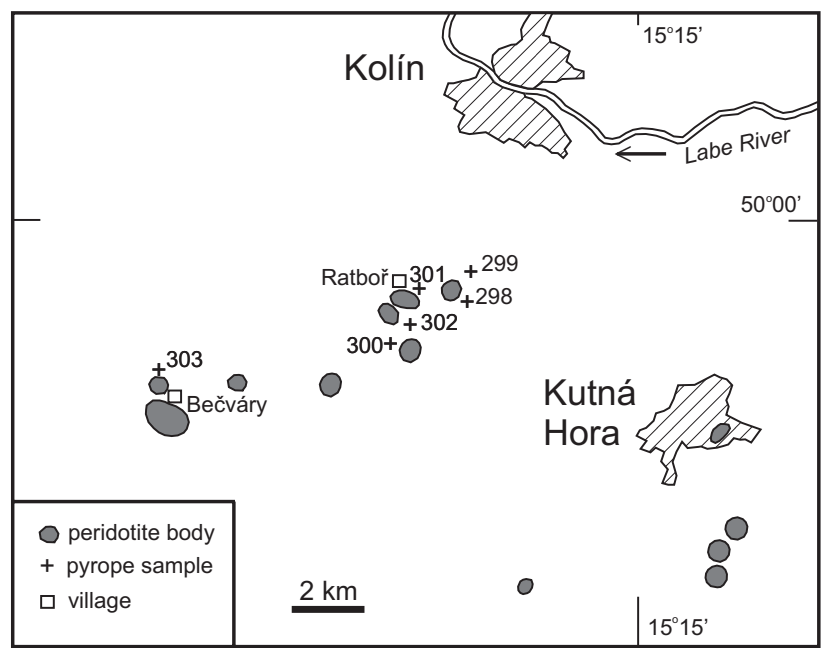

Fig. 2 Distribution of garnet peridotite bodies (based on airborne magnetic survey) and of the studied pyrope samples in the Kolín area.

(Polish Sudetes) area. In the latter area, HP granulites, eclogites and garnet peridotites show ages 400-380 Ma (O’Brien et al. 1997; Mazur et al. 2006; Anczkiewicz et al. 2007), i.e., palaeo-Variscan, whereas in the Moldanubian Zone of the Bohemian Massif similar HP rocks yield neo-Variscan ages of $340 \mathrm{Ma}$ (Aftalion et al. 1989; Wendt et al. 1994; Becker 1997; Kröner et al. 2000; Sláma et al. 2007; O’Brien 2008; Sláma et al. 2008). Notably, garnet clinopyroxenite layers in Bečváry garnet peridotite in KHCU have been dated at $377 \pm 20 \mathrm{Ma}$ (Brueckner et al. 1991). In effect, the Variscan metamorphic units in the Bohemian Massif can be seen as resulting from a superposition of two Variscan orogenic belts (paleo- and neo-Variscan), with age difference of $\sim 40 \mathrm{Ma}$.

Garnet peridotites, from which pyrope was released by weathering, occur as allochthonous, tectonically implanted slices in crustal metamorphic rocks of the Kutná Hora Crystalline Unit (KHCU) (Fig. 2). Polymetamorphic migmatitic gneisses, orthogneisses, amphibolites, eclogites, and some felsic kyanite-bearing granulites constitute KHCU, which was divided into several allochthonous partial units (Synek and Oliveriová 1993). Details of local geology are shown in the geological map 1:50,000, sheet 13-32 Kolín. The KHCU area is extensively covered by Quaternary and partly by late Cretaceous deposits. Peridotites are exposed only in some small river valleys. For this reason, information from airborne magnetic survey was used to contour the peridotite bodies (Fig. 2). At places, e.g. around Ratboř village (Fig. 2), there are additional small peridotite lenses, too small to be shown at this scale. Use of detrital pyrope populations obtained by panning from the Quaternary sediments along small streams was preferred to acquire effective pilot character- 
istics of mineral inclusions in pyrope from the given area. Garnet composition shows some variation, indicating derivation of pyrope from somewhat variable olivinerich ultramafic rocks. It is obvious that the majority of pyrope occurs in the Quaternary sediments as a first-cycle detrital material and only a relatively small proportion was recycled from basal sediments of the Cenomanian age (Žítt et al. 1999; Běhal et al. 2000).

\section{Samples}

The studied pyrope samples (Tab. 1) are panning and handpicking concentrates from sediments of local streams. Garnet grains are typically $2-3 \mathrm{~mm}$, and exceptionally $4 \mathrm{~mm}$, in diameter. Grains were embedded in resin and polished for microprobe analyses. Study of polished samples using reflected light microscope was aimed at selecting suitable garnet grains containing mineral inclusions, and marked in sample photographs to expedite work with the microprobe.

Tab. 1 Location and type of samples

\begin{tabular}{cllcc}
\hline $\begin{array}{c}\text { Sample } \\
\text { No. }\end{array}$ & \multicolumn{1}{c}{ locality } & village & map sheet & $\begin{array}{c}\text { year of } \\
\text { sampling }\end{array}$ \\
\hline 298 & brook & Hranice & $13-322$ & 2002 \\
299 & "Granátnice" & Hranice & $13-322$ & 1999 \\
300 & "Jordán" brook & Sedlov & $13-322$ & 2000 \\
301 & small river & Ratboř & $13-322$ & 2002 \\
302 & brook & Bořetice & $13-322$ & 2002 \\
303 & next to quarry & Bečváry & $13-323$ & 2004 \\
\hline
\end{tabular}

\section{Analytical methods}

Analyses were conducted using CAMECA SX 100 electron microprobe in WDS mode $(15 \mathrm{kV}, 20$ and $10 \mathrm{nA})$ in the Joint laboratory of the Department of Geological Sciences of the Masaryk University and the Czech Geological Survey, Brno. The following minerals and compounds were used as standards: $\mathrm{Si}, \mathrm{Al}, \mathrm{K}$ - sanidine, $\mathrm{Ti}$ - hornblende, $\mathrm{Fe}$ - andradite, $\mathrm{Cr}$ - chromite, $\mathrm{Mn}$ - rhodonite, $\mathrm{Mg}$ - olivine for silicates, spinel for oxides, $\mathrm{Ca}$ - andradite, $\mathrm{Na}$-albite, $\mathrm{Ba}$ - baryte, $\mathrm{Nb}$ - columbite, $\mathrm{Zr}$ - zircon, $\mathrm{P}$ - apatite, $\mathrm{Ni}$ Ni metal, F - fluorine riebeckite and topaz, $\mathrm{Cl}$ - vanadinite. Sodium in garnet was analysed with TAP crystal, time of measurement $30 \mathrm{~s}$ on peak, $15 \mathrm{~s}$ on background. Titanium was analysed with LPET crystal, time of measurement $20 \mathrm{~s}$ on peak, $10 \mathrm{~s}$ on background. Error of the determination (expresssed as two standard deviations, $2 \sigma$ ) for $\mathrm{Na}_{2} \mathrm{O}$ is 0.053 wt. $\%$ and for $\mathrm{TiO}_{2} 0.071$ wt. \%. Phosphorus content in pyrope was always below, and practically all measured $\mathrm{TiO}_{2}$ values above, two-sigma. Programme GCDkit (Janoušek et al. 2006) was used for plotting the data.

\section{Results}

\subsection{Pyrope}

Table 2 presents nine analyses on several grains in four samples. Sample locations are shown in Fig. 2. Electron microprobe analyses (EMPA) included determination of 10 elements; Ti, Na and $\mathrm{P}$ were analysed in all cases. Garnet composition shows limited variation with Prp 67.9-71.6, Alm 13.3-18.9, Grs 2.0-7.5 and Uvr 2.6-9.6 mol. \%.

Recalculation of analyses was done on the basis of eight cations and ferric-ferrous estimation by stoichiometry was avoided, because of imprecision of major-element abundances. According to some examples in the literature (Deer et al. 1997), $\mathrm{Fe}^{3+}$ and $\mathrm{Ti}$ in pyropic garnets from peridotites are combined in the shorlomite molecule. In the present case with calculation of all $\mathrm{Fe}$ as ferrous, the small quantity of $\mathrm{Ti}$ is calculated as a "Ti-grossular" molecule $\left[\mathrm{Ca}_{3}(\mathrm{AlTi})_{2}\left(\mathrm{Si}_{2} \mathrm{Al}\right)_{3} \mathrm{O}_{12}\right]$, corresponding to $c .2$ mol. $\%$ in the analysed pyropes. This alternative finds support in crystal-chemical studies of Ti bonding in $\mathrm{Ca}$ rich garnets (Dowty 1971).

Analyses in Tab. 2 indicate variation in composition of garnet peridotite in the Kolín area and/or variation in the element partitioning among major minerals. Garnet composition is very uniform through a single grain. Narrow rims, which might be affected by late diffusion associated with decompressional stage, were removed by natural grain abrasion, as were the polymineralic (Opx, Amp, Spl) kelyphitic reaction rims. With regard to the relatively low $\mathrm{TiO}_{2}$ and $\mathrm{Na}_{2} \mathrm{O}$ content in pyrope from the Kolín area, a comparison was undertaken with pyrope from currently exploited Podsedice and Vestřev localities (Fig. 1) in northern Bohemia, which is presented below.

\subsection{Magnesian ilmenite}

Ilmenite occurs in three forms: (a) Irregular inclusions of magnesian ilmenite in pyrope, which are to $60 \mu \mathrm{m}$ across (Fig. 3a), with Mn-rich rims containing up to $25 \mathrm{~mol}$. $\%$ pyrophanite. The relations indicate that the $\mathrm{MnMg}_{-1}$ exchange at rims proceeded up to nearly complete removal of Mg. Only two grains of this type enclosed in a single crystal of pyrope have been found (sample 301). Compositional profile in the host garnet adjacent to the ilmenite inclusion shows uniform, ordinary $\mathrm{MnO}$ contents of $0.23-0.30 \mathrm{wt} . \%$, indicating that these ilmenite grains are possibly xenocrysts, which experienced Mn-enrichment prior to becoming enclosed in garnet. (b) Ordinary magnesian ilmenite showing no Mn enrichment. It occurs individually or in polymineralic clusters (Fig. 3b). Some larger irregular grains contain an unmixed (?) or an ad- 
Tab. 2 Pyrope analyses from the Kolín area

\begin{tabular}{|c|c|c|c|c|c|c|c|c|c|}
\hline Analysis No. & 27 & 28 & 39 & 44 & 47 & 49 & 1 & 17 & 34 \\
\hline Sample No. & 300 & 300 & 300 & 300 & 300 & 300 & 303 & 301 & 299 \\
\hline $\mathrm{SiO}_{2}$ & 42.67 & 42.34 & 42.49 & 42.36 & 42.66 & 42.56 & 42.44 & 42.38 & 42.32 \\
\hline $\mathrm{P}_{2} \mathrm{O}_{5}$ & 0.04 & 0.03 & 0.02 & 0.04 & 0.04 & 0.05 & 0.05 & 0.05 & 0.00 \\
\hline $\mathrm{TiO}_{2}$ & 0.39 & 0.50 & 0.31 & 0.39 & 0.47 & 0.05 & 0.39 & 0.23 & 0.26 \\
\hline $\mathrm{Al}_{2} \mathrm{O}_{3}$ & 22.30 & 21.98 & 20.91 & 21.59 & 21.91 & 22.34 & 21.96 & 22.44 & 21.34 \\
\hline $\mathrm{Cr}_{2} \mathrm{O}_{3}$ & 1.50 & 1.49 & 3.37 & 2.14 & 1.58 & 1.57 & 0.90 & 1.33 & 2.45 \\
\hline $\mathrm{FeO}^{\mathrm{t}}$ & 7.89 & 7.87 & 6.67 & 7.24 & 7.78 & 7.96 & 9.39 & 7.90 & 7.74 \\
\hline $\mathrm{MnO}$ & 0.26 & 0.27 & 0.28 & 0.27 & 0.29 & 0.32 & 0.25 & 0.29 & 0.32 \\
\hline $\mathrm{MgO}$ & 20.29 & 19.97 & 19.87 & 20.03 & 19.81 & 19.65 & 18.92 & 20.02 & 19.26 \\
\hline $\mathrm{CaO}$ & 4.62 & 4.64 & 5.53 & 4.87 & 4.75 & 4.78 & 4.63 & 4.50 & 5.31 \\
\hline $\mathrm{Na}_{2} \mathrm{O}$ & 0.06 & 0.09 & 0.03 & 0.05 & 0.07 & 0.00 & 0.08 & 0.00 & 0.06 \\
\hline Total & 100.02 & 99.21 & 99.49 & 99.02 & 99.36 & 99.28 & 99.00 & 99.15 & 99.05 \\
\hline \multicolumn{10}{|l|}{ Atoms (8 cats) } \\
\hline $\mathrm{Si}$ & 3.033 & 3.037 & 3.050 & 3.046 & 3.058 & 3.053 & 3.067 & 3.039 & 3.054 \\
\hline $\mathrm{Ti}$ & 0.021 & 0.027 & 0.017 & 0.021 & 0.025 & 0.003 & 0.021 & 0.012 & 0.014 \\
\hline $\mathrm{Al}$ & 1.868 & 1.859 & 1.769 & 1.830 & 1.851 & 1.889 & 1.871 & 1.897 & 1.815 \\
\hline $\mathrm{Cr}$ & 0.084 & 0.085 & 0.191 & 0.122 & 0.090 & 0.089 & 0.051 & 0.075 & 0.140 \\
\hline $\mathrm{Fe}^{2+}$ & 0.469 & 0.472 & 0.400 & 0.435 & 0.466 & 0.478 & 0.567 & 0.474 & 0.467 \\
\hline Mn & $0 ., 016$ & 0.016 & 0.017 & 0.016 & 0.018 & 0.019 & 0.015 & 0.018 & 0.020 \\
\hline $\mathrm{Mg}$ & 2.149 & 2.135 & 2.126 & 2.147 & 2.117 & 2.101 & 2.038 & 2.140 & 2.072 \\
\hline $\mathrm{Ca}$ & 0.352 & 0.357 & 0.425 & 0.375 & 0.365 & 0.367 & 0.358 & 0.346 & 0.411 \\
\hline $\mathrm{Na}$ & 0.008 & 0.013 & 0.004 & 0.007 & 0.010 & 0.000 & 0.011 & 0.000 & 0.008 \\
\hline \multicolumn{10}{|l|}{ Mol. \% } \\
\hline Prp & 71.6 & 71.2 & 70.9 & 71.6 & 70.6 & 70.0 & 67.9 & 71.3 & 69.1 \\
\hline Alm & 15.6 & 15.7 & 13.3 & 14.5 & 15.5 & 15.9 & 18.9 & 15.8 & 15.6 \\
\hline Sps & 0.5 & 0.5 & 0.6 & 0.5 & 0.6 & 0.6 & 0.5 & 0.6 & 0.7 \\
\hline Uvar & 4.2 & 4.3 & 9.6 & 6.1 & 4.5 & 4.5 & 2.6 & 3.7 & 7.0 \\
\hline Grs & 3.5 & 2.8 & 2.0 & 2.8 & 3.4 & 7.5 & 4.1 & 5.9 & 4.1 \\
\hline Ti-Grs ${ }^{*}$ & 2.1 & 2.7 & 1.7 & 2.1 & 2.5 & 0.3 & 2.1 & 1.2 & 1.4 \\
\hline
\end{tabular}

${ }^{*}$ see explanation in text

jacent rutile grain. Analyses of ilmenite type (a) and (b) from inclusions in several pyrope grains are plotted in Fig. 4. The compositions correspond mainly to magnesian ilmenite, with 40-45 mol. \% geikielite and ilmenite with up to 25 mol. \% pyrophanite. (c) Sample 300 contains a rare example of platy magnesian ilmenite crystals (seen as elongated/lamellar sections) with a regular orientation in the host pyrope (Fig. 5). The lamellar shape and size of this ilmenite phase is similar to acicular rutile and it is considered to have formed probably by unmixing from pyrope. Spot analyses of some lamellae up to $6 \mu \mathrm{m}$ wide show absence of Mn enrichment and a composition comparable with that of type (b) magnesian ilmenite.

\subsection{Rutile}

Rutile forms nearly equant grains 15 to $30 \mu \mathrm{m}$ across, usually in polymineralic aggregate inclusions, as thick lenticular grains probably (?) unmixed from ilmenitegeikielite, and acicular crystals with regular orientation in some pyrope grains. In addition to $\mathrm{Ti}$, coarse rutile contains minor $\mathrm{Fe}, \mathrm{Mg}, \mathrm{Cr}, \mathrm{V}$ and up to 0.32 wt. $\% \mathrm{ZrO}_{2}$ (Tab. 3). Acicular rutile crystals form a regular, oriented framework in pyrope, which is striking when observed under binocular microscope in incadescent light, in faceted pieces, or in thick sections (Fig. 6). There is a significant variation as many pyrope grains are nearly free of rutile inclusions or contain only a few of them. An estimate of total rutile content in pyrope was done using a $0.5 \mathrm{~mm}$ thick section of pyrope from sample 300 , which contains an extraordinary quantity of acicular rutile (Fig. 6). The total volume of the measured part of the grain was $1.56 \mathrm{~mm}^{3}$ (Fig. 6). Average dimensions of cross-section of rutile needles were estimated to be 4 by $4 \mu \mathrm{m}$; total number and length of rutile prisms was counted. The calculated volume of the acicular rutile is 0.052 vol. $\%$ of the host pyrope. As the density of rutile (c. 4.23$)$ is higher than that of pyrope $(\sim 3.7)$, the weight percentage of $\mathrm{TiO}_{2}$ is approximately 0.059 . Assuming that all acicular rutile formed by unmixing of $\mathrm{Ti}$ from the host pyrope, the original content of $\mathrm{TiO}_{2}$ in pyrope would be by 0.06 wt. $\%$ higher than the present content. 

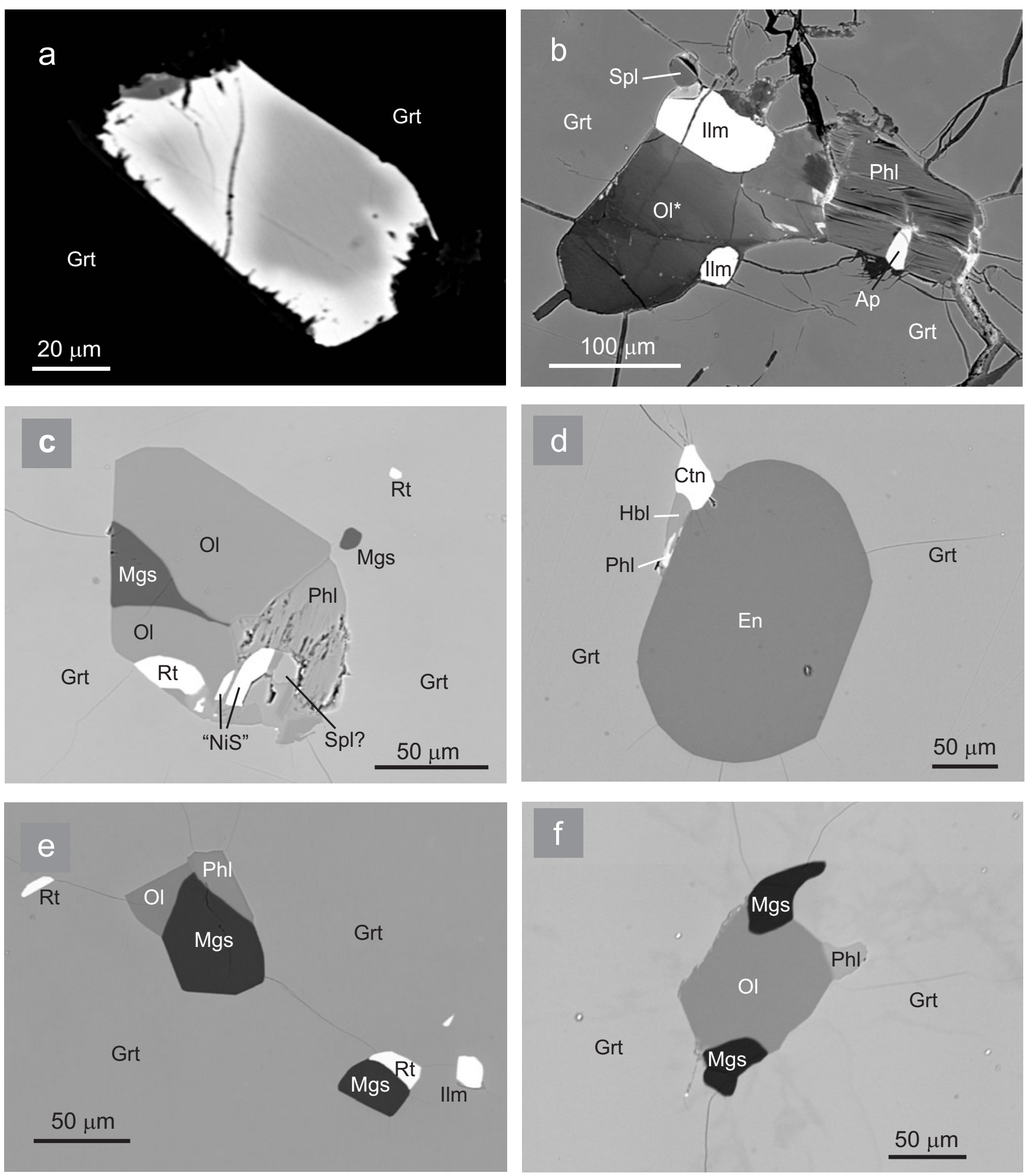

Fig. 3 Back-scattered electron (BSE) images of inclusions in pyrope. Abbreviations for minerals: Grt garnet, Ol* altered olivine, Phl phlogopite, Ilm magnesian ilmenite, Spl spinel, Ap apatite, Ol olivine, Mgs magnesite, Rt rutile, "NiS" Ni-sulphide, Ctn crichtonite-series? mineral, Hbl pargasite, En enstatite. a - Inclusion of magnesian ilmenite with Mn-rich rim seen as light domains. b - Polymineralic inclusion of magnesian ilmenite, altered olivine, phlogopite, spinel, and apatite. c-Polymineralic inclusion of olivine, magnesite, rutile, phlogopite, spinel? and Ni-sulphide. d - Inclusion of enstatite with attached phlogopite, pargasite and a crichtonite-series? mineral. $\mathbf{e}$ - Polymineralic inclusions of magnesite, olivine, phlogopite, and rutile. f - Polymineralic inclusion of olivine, magnesite and phlogopite. 


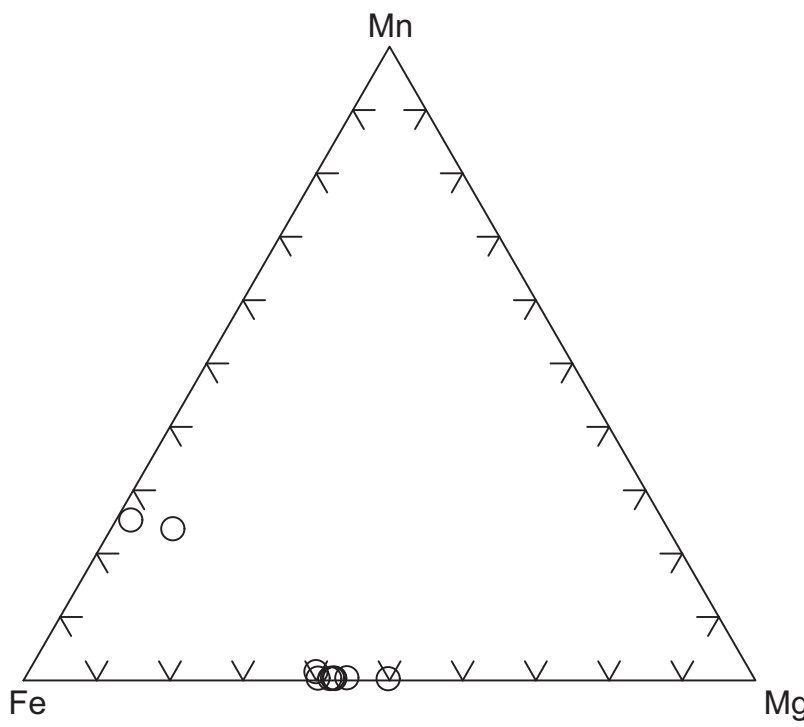

Fig. 4 Ternary plot ilmenite (Fe), pyrophanite (Mn) and geikielite (Mg) with ten analyses of ilmenite-geikielite and manganoan ilmenite from the Kolín area.

\subsection{Spinel}

Spinel inclusions are rather rare and typically smaller than $20 \mu \mathrm{m}$ (Fig. 3b). The analysis in Tab. 3 corresponds approximately to $2 / 3$ of the $\mathrm{Mg}$-spinel $\left(\mathrm{MgAl}_{2} \mathrm{O}_{4}\right)$ and $1 / 3$ of chromite $\left(\mathrm{FeCr}_{2} \mathrm{O}_{4}\right)$ components. Occurrence of spinel as a part of polymineralic inclusion clusters is typical.

\subsection{Olivine}

Olivine inclusions were observed in several pyrope crystals. They are 50 to $100 \mu \mathrm{m}$ in diameter, occur individually or in polymineralic clusters with phlogopite, rutile, Ni-sulphide, and magnesite (Fig. 3c). Some olivine crystals are euhedral (Fig. 3c), but the faces may represent negative crystal shapes of the host pyrope. The analyses correspond to $93.6-93.7 \mathrm{~mol}$. \% forsterite component, analysis No. 23 corresponds to $0.55 \mathrm{~mol}$ \% Ni-olivine. The highly magnesian composition of olivine inclusions in pyrope is probably due to $\mathrm{Mg}-\mathrm{Fe}$ exchange between olivine and garnet. Olivine is typically rather fresh but in fractured pyrope the olivine inclusions are partly or completely altered to minerals compositionally related to antigorite-chrysotile and Mg-chlorite (?).

\subsection{Enstatite}

The single observed enstatite inclusion is a subhedraleuhedral crystal $200 \mu \mathrm{m}$ long (Fig. 3d). The analyses correspond to $93.7 \mathrm{~mol}$ \% enstatite end-member with 0.5

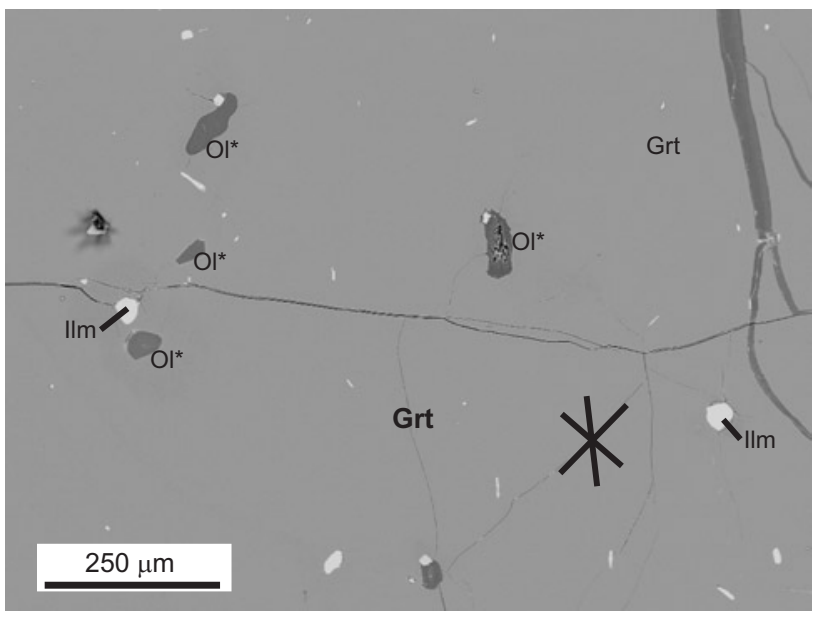

Fig. 5 Sections through (unmixed?) platy magnesian ilmenite in pyrope. A schematic orientation of inclusions is indicated by black intersecting lines. Other inclusions are $\mathrm{Ol}^{*}$ (altered olivine), and probably primary (nearly equant) magnesian ilmenite (Ilm), 30-50 $\mu \mathrm{m}$.

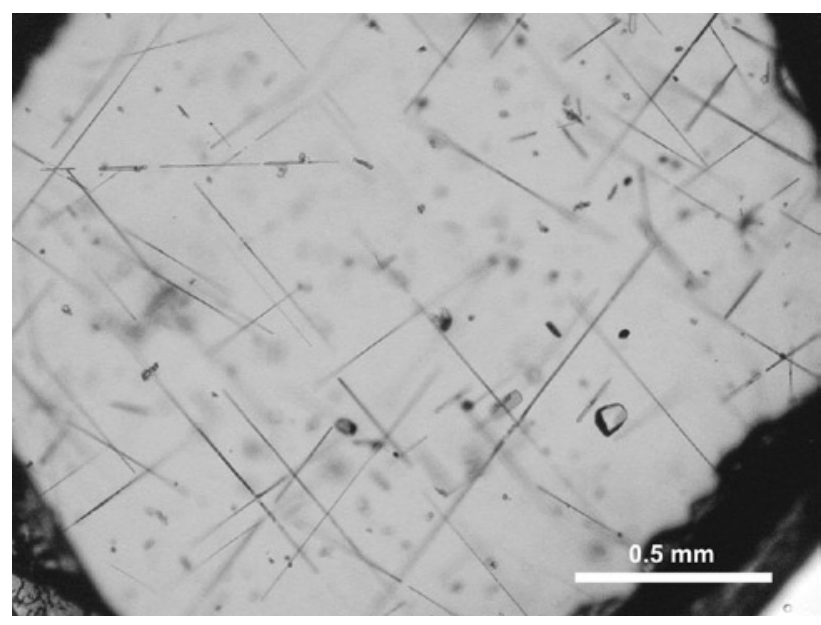

Fig. 6 Regular orientation of acicular rutile in $0.5 \mathrm{~mm}$ thick section of pyrope. Sample 300 , transmitted light.

mol. \% wollastonite, and very low $\mathrm{Mn}, \mathrm{Ni}$ and $\mathrm{Al}(0.55$ wt. $\% \mathrm{Al}_{2} \mathrm{O}_{3}$ ) and Ti contents.

\subsection{Pargasite}

The single analysed amphibole crystal is $40 \mu \mathrm{m}$ long (Fig. 3d), corresponding in composition to pargasite (Tab. 3). It is attached, together with phlogopite and a crichtonite-series? mineral, to a large enstatite crystal. With a content of $6.37 \mathrm{Si}$ apfu it plots close to the edenite compositional field (Leake et al. 1997). The hydroxyl site is probably occupied largely by $\mathrm{OH}$, as the pargasite contains only 0.03 wt. $\% \mathrm{Cl}$ and $\mathrm{F}$ is below the detection limit. 


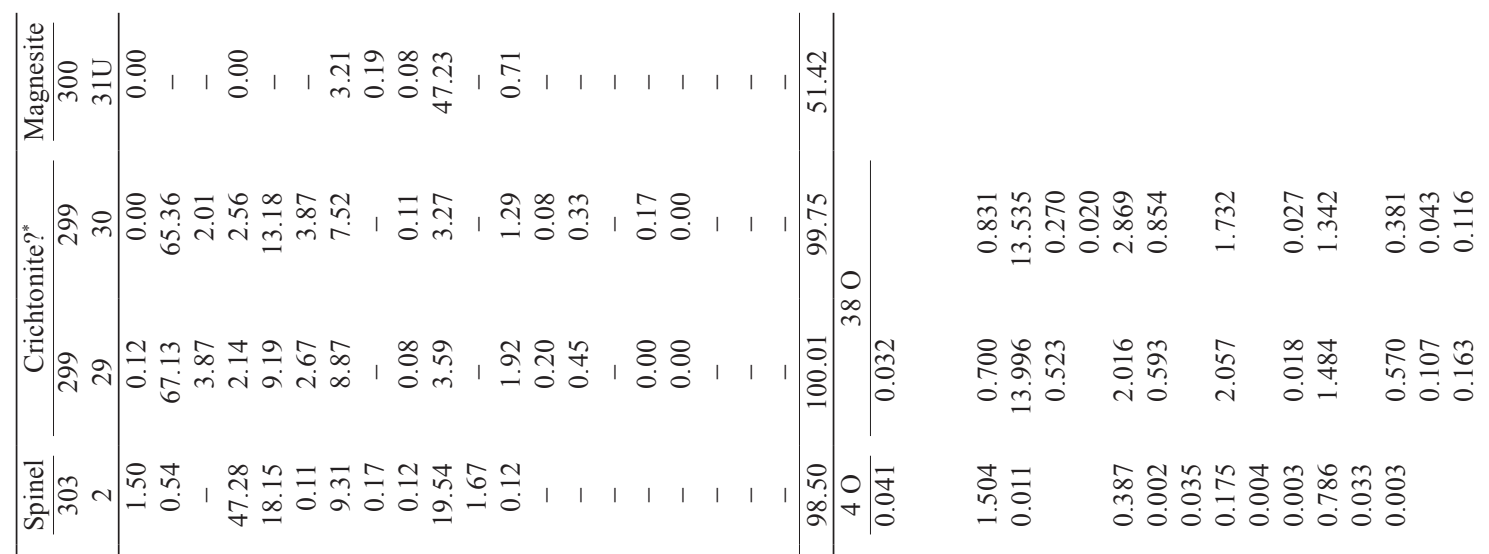

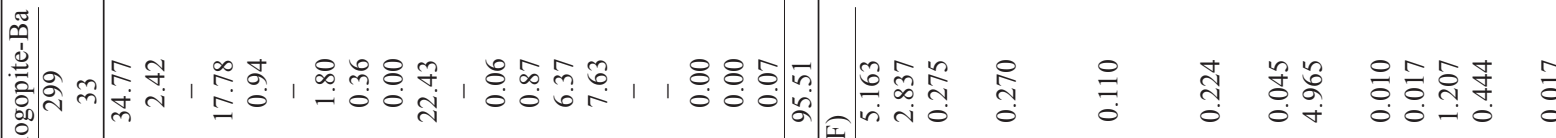
$\frac{\circ}{2}$

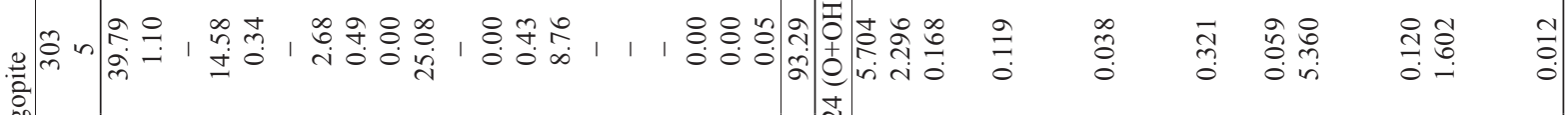

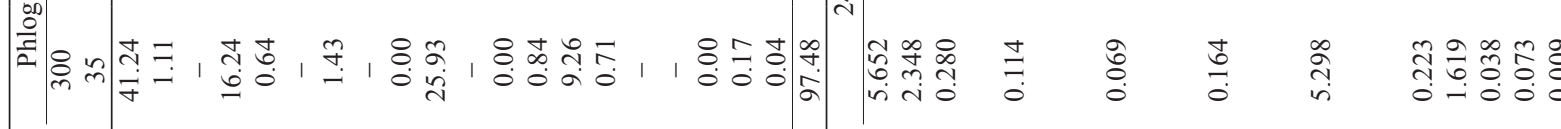

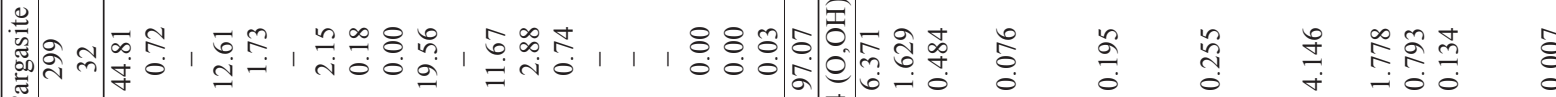

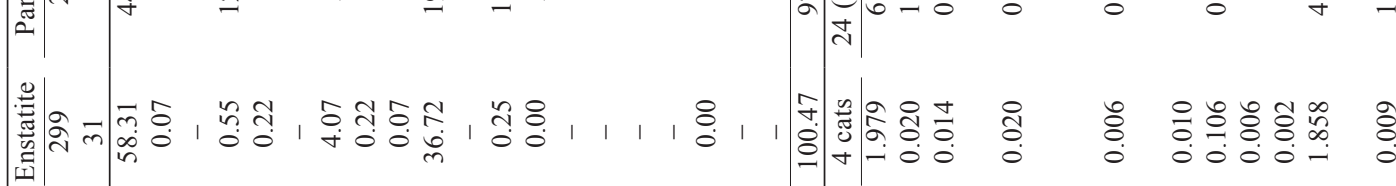

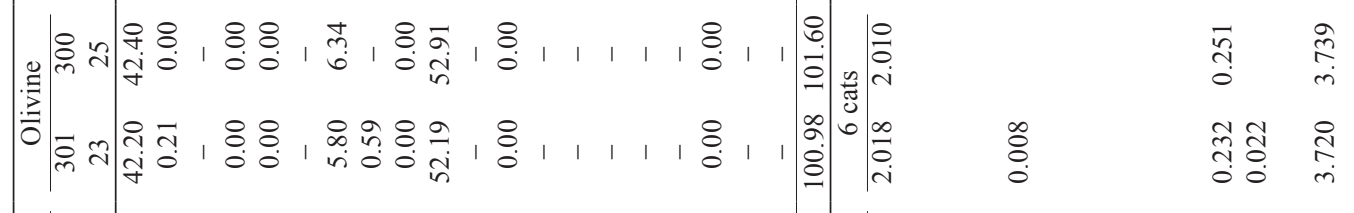




\subsection{Phlogopite and barian phlogopite}

Phlogopite is not so rare among inclusions in pyrope. It typically occurs as flakes $25-120 \mu \mathrm{m}$ long in polymineralic inclusions (Fig. 3b, e). The composition is near the magnesian end-member, with some enrichment in chromium ( 0.34 to 0.94 wt. $\% \mathrm{Cr}_{2} \mathrm{O}_{3}$ ), nickel (up to 0.49 wt. \% NiO), and a slight enrichment in sodium. Barium contents are slightly elevated, and one crystal contains 7.63 wt. $\% \mathrm{BaO}$ corresponding to $26.6 \mathrm{~mol}$. \% of the barian end-member. Halogen contents are low, 0.04-0.07 wt. $\% \mathrm{Cl}$ and 0 to $0.17 \mathrm{wt} \% \mathrm{~F}$, indicating a strong predominance of the $\mathrm{OH}$ group (Tab. 3).

\subsection{Magnesite}

Magnesite occurs as anhedral to subhedral inclusions 10 to $50 \mu \mathrm{m}$ in size, usually associated with olivine (Fig. 3c, e, f) or phlogopite, rutile and Ni-sulphide. Textures indicate equlibrium relations with the associated minerals, and accompanying olivine is free of alteration. Magnesite contains 3.2 wt. \% FeO, low $\mathrm{CaO}, \mathrm{NiO}$, and $\mathrm{MnO}$ (Tab. 3). Such a composition closely compares with magnesite compositions in pyropes of garnet peridotites from localities worldwide. Assemblages with periclase, dolomite, and calcite (Yang et al. 1993) were not observed in the Kolín samples.

\subsection{Crichtonite-series mine- ral (loveringite)?}

Only a single grain of this type has been observed and analysed (Fig. 3d, Tab. 3). In the absence of structural data the mineral is somewhat tentatively compared with the crichtonite-series minerals. In Tab. 4 the analyses are compared with composition of chrichtonite-type phase in pyrope-rich garnet from Garnet Ridge, Arizona (Wang et al. 1999) and with armalcolite analyses from kimberlites. Crystallisation of kimberlitic armalcolites is ascribed to melts modified by metasomatic processes (Haggerty 1991).

The crichtonite-series minerals with a general formula $\mathrm{AM}_{21} \mathrm{O}_{38}$ are and armalcolite named according to the predominant single large cation per formula unit. In our case the sum of large cations $(\mathrm{Ca}, \mathrm{K}, \mathrm{Na})$ corresponds to more than $50 \%$ of the $\mathrm{A}$ site (Tab. 3). The mineral from the Kolín area does not contain detectable RE elements, but it has a low content of uranium (probably $<3$ wt. $\% \mathrm{UO}_{2}$ ) indicated by inspection of qualitative spectra. It is most probable that uranium, which was not determined quantitatively, also entered the A position. The total for small cations occupying the $\mathrm{M}$ site (mainly $\mathrm{Ti}, \mathrm{Cr}, \mathrm{Fe}, \mathrm{Mg}, \mathrm{V}$, and $\mathrm{Zr}$ ) is near 21 . This makes the mineral closely related to loveringite, $(\mathrm{Ca}, \mathrm{Ce}) \mathrm{M}_{21} \mathrm{O}_{38}$, with the difference that a small amount of $\mathrm{U}$ is present instead of REE. Details of crystal chemistry of this mineral can be clarified only on the basis of new analyses.

Tab. 4 Comparison of Ti-Zr-Cr-V-Fe-Mg oxide with crichtonite-series? minerals

\begin{tabular}{|c|c|c|c|c|c|}
\hline \multirow[b]{2}{*}{ Analysis No. } & \multicolumn{2}{|c|}{ Kolín area } & \multicolumn{2}{|c|}{$\begin{array}{l}\text { Crichtonite-series, } \\
\text { Garnet Ridge, } \\
\text { Wang et al. (1999) }\end{array}$} & \multirow{2}{*}{$\begin{array}{c}\text { Armalcolite from kimberlites } \\
\text { (Haggerty 1991), } \mathrm{n}=8 \\
\text { range }\end{array}$} \\
\hline & 29 & 30 & $4(40)$ & $1(34)$ & \\
\hline $\mathrm{SiO}_{2}$ & 0.12 & 0.00 & 0.03 & 0.07 & $0.00-0.28$ \\
\hline $\mathrm{TiO}_{2}$ & 67.13 & 65.36 & 53.62 & 68.62 & $70.12-79.90$ \\
\hline $\mathrm{ZrO}_{2}$ & 3.87 & 2.01 & 2.34 & 4.07 & $0.00-1.93$ \\
\hline $\mathrm{HfO}_{2}$ & n.a. & n.a. & 0.10 & 0.12 & \\
\hline $\mathrm{Al}_{2} \mathrm{O}_{3}$ & 2.14 & 2.56 & 2.11 & 2.10 & $0.02-1.60$ \\
\hline $\mathrm{Cr}_{2} \mathrm{O}_{3}$ & 9.19 & 13.18 & 16.62 & 1.26 & $0.22-11.67$ \\
\hline $\mathrm{V}_{2} \mathrm{O}_{3}$ & 2.67 & 3.87 & 0.97 & 0.85 & \\
\hline $\mathrm{FeO}$ & 8.67 & 7.52 & 10.81 & 11.61 & $5.45-13.47$ \\
\hline $\mathrm{MnO}$ & 0.08 & 0.11 & 0.09 & 0.11 & $0.05-3.70$ \\
\hline $\mathrm{MgO}$ & 3.59 & 3.27 & 3.22 & 4.21 & $5.53-13.43$ \\
\hline $\mathrm{NiO}$ & n.a. & n.a. & 0.14 & 0.51 & \\
\hline $\mathrm{CaO}$ & 1.92 & 1.29 & 0.49 & 2.33 & $0.00-4.31$ \\
\hline $\mathrm{BaO}$ & n.a. & n.a. & 1.05 & 1.49 & $0.00-0.77$ \\
\hline $\mathrm{Nb}_{2} \mathrm{O}_{3}$ & 0.00 & 0.17 & 0.11 & $<0.01$ & $0.00-1.14$ \\
\hline $\mathrm{Ta}_{2} \mathrm{O}_{3}$ & 0.00 & 0.00 & n.a. & n.a. & $0.00-0.05$ \\
\hline $\mathrm{La}_{2} \mathrm{O}_{3}$ & n.a. & n.a. & 2.68 & 0.01 & $0.00-0.18$ \\
\hline $\mathrm{Ce}_{2} \mathrm{O}_{3}$ & n.a. & n.a. & 1.86 & 0.38 & $0.00-0.08$ \\
\hline $\mathrm{SrO}$ & n.a. & n.a. & 3.56 & 0.71 & $0.00-0.22$ \\
\hline $\mathrm{Na}_{2} \mathrm{O}$ & 0.20 & 0.08 & 0.05 & 0.48 & $0.07-0.10$ \\
\hline $\mathrm{K}_{2} \mathrm{O}$ & 0.45 & 0.33 & 0.02 & 0.31 & $0.00-2.10$ \\
\hline Total & 100.01 & 99.75 & 99.88 & 99.21 & \\
\hline
\end{tabular}



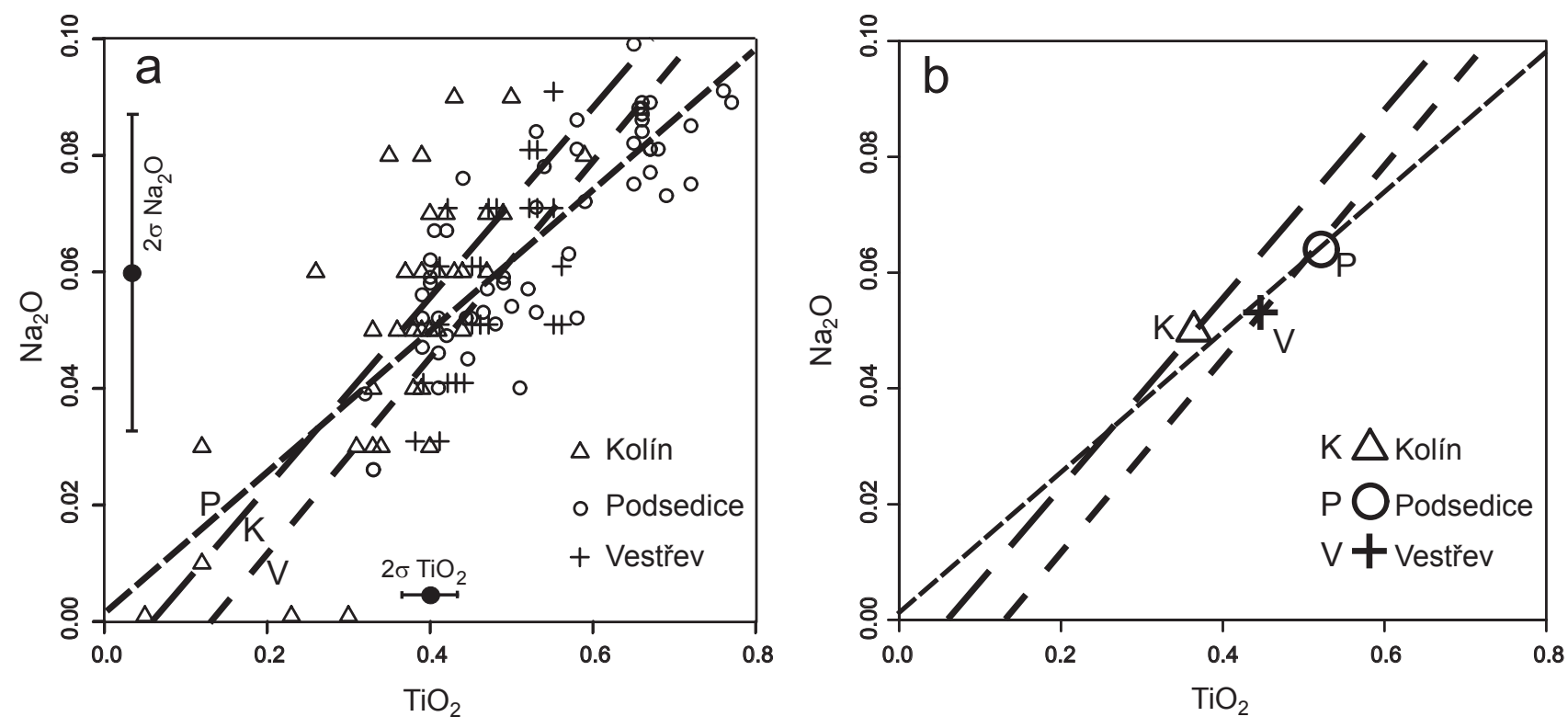

Fig. 7 a - Plot $\mathrm{TiO}_{2}$ vs. $\mathrm{Na}_{2} \mathrm{O}$ in pyrope from Kolín area $(\mathrm{n}=36)$, as well as Podsedice $(\mathrm{n}=66)$, and Vestřev $(\mathrm{n}=28)$ deposits. Two-sigma error bars for $\mathrm{Na}_{2} \mathrm{O}$ and $\mathrm{TiO}_{2}$ determinations are also shown. $\mathbf{b}$ - linear fits for the three groups and calculated average values.

\subsection{Sulphides and apatite}

Minute inclusions of Ni-sulphide $c .10-30 \mu \mathrm{m}$ long were observed in several pyrope grains, in polymineralic aggregates or as isolated inclusions (Fig. 3c). The sulphide, which is not identified more specifically, contained in all cases a small amount of Fe. Chalcopyrite was observed enclosed in pyrope in a single case. Apatite is present mainly in several polymineralic inclusions occuring as elongated subrounded grains 10-30 $\mu \mathrm{m}$ long (Fig. 3b). It is somewhat surprising that not a single example of zircon inclusion was noted, while Hyršl (2002) described possible zircon inclusions in Kolín pyropes. The present observations do not unequivocally exclude zircon as a possible inclusion.

\subsection{Comparison of $\mathrm{Ti}$ and $\mathrm{Na}$ contents in pyrope with data from Podsedice and Vestřev}

Pyrope grains accumulated in Pleistocene gravels near the Podsedice village (Fig. 1) represent material with a variety of recycling histories. Being derived from garnet peridotite bodies located in kyanite-garnet felsic granulites of the Ohře granulite unit of a local basement, some grains were first deposited in Permian sandstones, some were later re-deposited in the late Cretaceous sediments, whereas other batches were delivered to the surface via Neogene basaltoid breccia (Seifert and Vrána 2005).

In the Vestřev deposit (Fig. 1), pyrope occurs in alluvial gravels, where it was probably derived from eroded

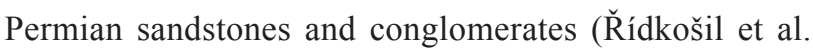
1997). No primary source of pyrope is known in proximity. Pyrope grains exhibit etched surface and occassional corrosion channels. Admittedly, the differences in erosion and re-deposition history of individual pyrope populations might have partly affected preservation of grains carrying mineral inclusions. The reason is the presence of microfractures due to compressibility and thermal expansion differences between pyrope host and the inclusions (Figs 3c, e, f).

Data on relatively low $\mathrm{TiO}_{2}$ contents and the presence of fine acicular rutile in Kolín pyrope prompted comparison of $\mathrm{TiO}_{2}$ and $\mathrm{Na}_{2} \mathrm{O}$ abundances in Kolín pyrope with a set of analyses of pyrope from Podsedice (Seifert and Vrána 2005) and from Vestřev (Fig. 7). The $\mathrm{TiO}_{2}$ vs. $\mathrm{Na}_{2} \mathrm{O}$ diagram is used with regard to correlation of these elements and tendency to substitution in garnet structure (Chopin and Ferraris 2003). All the analyses were obtained using the same apparatus operated at the same conditions. The mean $\mathrm{TiO}_{2}$ content in Kolín pyropes is lower by 0.15 wt. \% than the value for Podsedice pyrope.

\section{Discussion}

\subsection{Inclusions and unmixed phases}

Mineral inclusions in pyrope can be classified as (a) minerals which existed at the time of garnet growth and were passively included by pyrope, and (b) phases, which 
formed later from components unmixed from host garnet. Although regular, crystallographically controlled orientation of inclusions can strongly indicate formation via unmixing, epitactic growth may produce a similar regular pattern of inclusions (Wang et al. 1999). In the case of Garnet Ridge pyrope studied by Wang et al. (1999), the Fe-Ti oxide assemblage constituted oriented acicular aggregates, which were somewhat inrregular in shape and up to $15 \mu \mathrm{m}$ wide. They are thus different from the rather thin and monomineralic rutile prisms/needles in pyrope from the Kolín area (Fig. 6).

\subsection{Variation in $\mathrm{Ti}$ and $\mathrm{Na}$ contents in studied pyropes}

The entry of sodium in garnet structure occurs in natural samples and in experiments (Sobolev and Lavrentyev 1971; Stachel et al. 2000; Bobrov et al. 2007). With increasing pressure, the majoritic substitution $\mathrm{NaSiM}^{2+} \mathrm{Al}_{-1}$ [where $\mathrm{M}^{2+}$ denotes $(\mathrm{Ca}, \mathrm{Mg}, \mathrm{Fe})^{2+}$ cations] takes place. The mechanism of Ti entry in garnet structure involves potentially both octahedral and tetrahedral sites. Owing to the relatively low Ti contents in the analysed pyropes, the actual mechanism of Ti bonding is uncertain. A coupled substitution of $\mathrm{Na}^{+}+\mathrm{Ti}^{4+}$ for $\mathrm{Ca}^{2+}+\mathrm{Al}^{3+}$ has also been proposed (Enami et al. 1995; Vrána and Frýda 2003). With regard to quantitative disparity of $\mathrm{Na}$ and $\mathrm{Ti}$, some additional mechanism of Ti entry took place (see Dowty 1971)

In Fig. 7 is plotted $\mathrm{Na}_{2} \mathrm{O}$ vs. $\mathrm{TiO}_{2}$ diagram for analyses of pyrope from the Kolín area, Podsedice and Vestřev. As indicates the large two-sigma error for $\mathrm{Na}_{2} \mathrm{O}$ determination, the $\mathrm{Na}_{2} \mathrm{O}$ values are of a semi-quantitative character only. Yet, it is useful to plot $\mathrm{Na}_{2} \mathrm{O}$ vs. $\mathrm{TiO}_{2}$ as means of showing variation in $\mathrm{TiO}_{2}$. Data in Tab. 2 indicate respective $\mathrm{Na}$ and Ti cation numbers corresponding to $\mathrm{Na}_{2} \mathrm{O}$ and $\mathrm{TiO}_{2}$ weight percentages.

In Kolín pyrope, the $\mathrm{TiO}_{2}$ content ranges from 0.05 to 0.76 wt. $\%$ and the $\mathrm{Na}_{2} \mathrm{O}$ content mainly from 0.03 to 0.09 wt. \%; there are few outlier values of $\mathrm{Na}_{2} \mathrm{O}$ near zero. There is a significant variation in average $\mathrm{TiO}_{2}$ content calculated for 36 Kolín pyrope analyses $\left(0.37\right.$ wt. $\left.\% \mathrm{TiO}_{2}\right), 28$ Vestřev analyses $\left(0.46\right.$ wt. $\left.\% \mathrm{TiO}_{2}\right)$ and 66 Podsedice analyses $\left(0.52\right.$ wt. $\left.\% \mathrm{TiO}_{2}\right)$. No oriented pyroxene exsolutions, indicating presence of a former majorite component, and reported from several localities abroad (Chopin and Ferraris 2003), have been observed in Kolín pyropes.

If the Ti content in Kolín pyrope were originally similar to that in Podsedice pyrope, the abundance of acicular rutile should be higher approximately by a factor of 2.5 , compared to the observation of pyrope grains rich in rutile. As the quantity of acicular rutile in Kolín pyrope is highly variable and some grains are nearly free of rutile inclusions, it is difficult to identify or estimate various factors resulting in the given situation. Nevertheless, among the three compared areas, only pyrope from Kolín area contains common or relatively abundant acicular rutile.

\subsection{Accessory minerals as carriers of minor- and trace-elements}

Some mineral inclusions in pyrope carry elevated contents of trace elements, which are present in the major minerals of pyrope peridotites only in very low amounts. The presence of such minerals gives information on element partitioning and whole-rock mass balance, even if the quantities of such inclusions are low. Examples include zirconium content in rutile and crichtonite-series? mineral (max. 3.87 wt. \% $\mathrm{ZrO}_{2}$ ) and barium in barian phlogopite (max. 7.63 wt. \% $\mathrm{BaO}$ ). Moreover, $\mathrm{CO}_{2}$ is an essential component in magnesite, and $(\mathrm{OH})$ group in amphibole and phlogopite being near the maximum content indicated by stoichiometry, as the contents of $\mathrm{Cl}$ and $\mathrm{F}$ are low. The mineral analyses provide information on $\mathrm{Cr}$ partitioning among pyrope, amphibole, phlogopite, spinel, and crichtonite-group? mineral and on $\mathrm{Ni}$ distribution among sulphide, olivine, spinel, enstatite, and amphibole.

\subsection{Magnesian ilmenite}

Microprobe analyses and textural observations indicate considerable complexity in ilmenite mineralogy. The individual types of ilmenite probably evolved during distinct stages of solidification and cooling of the host garnet peridotite. Two of the three types, i.e., (a) inclusions of magnesian ilmenite with Mn-rich rims containing up to 25 mol. \% pyrophanite (Fig. 3a) and (c) platy magnesian ilmenite crystals with a regular orientation in the host pyrope (Fig. 5), are each confined to a single garnet grain. This rarity contributes to uncertainty in genetic interpretation and somewhat enigmatic status. The most abundant ordinary magnesian ilmenite, type (b) (Fig. 3b), compares with other known ilmenite occurrences in pyrope. Wang et al. (1999) have described ilmenite-geikielite with 50-60 mol. \% geikielite component as inclusions in pyrope from diatremes in Arizona. Alberico et al. (2003) have reported acicular ilmenite with the composition $\left(\mathrm{Mg}_{0.52} \mathrm{Fe}_{0.48}\right) \mathrm{TiO}_{3}$ as microinclusions in Foltea (Southern Carpathians) pyropes with estimated P-T conditions of 2.2-2.4 GPa and $1150-1300^{\circ} \mathrm{C}$.

In the Kolín area, the absence of Mn enrichment in small ilmenite particles of the types (b) and (c) indicates that a significant late $\mathrm{Mn}-\mathrm{Mg}$ exchange between ilmenite 
and the host garnet did not take place. Unlike magnesian ilmenite nodules from kimberlites (Haggerty 1991), the analysed magnesian ilmenite inclusions in pyrope are practically free of ferric iron.

\subsection{Magnesite}

Primary magnesite inclusions in pyrope, which crystallized under mantle conditions of the pyrope peridotites, have been documented from several occurrences worldwide (Kushiro et al. 1975; Yang et al. 1993; Zhang and Liou 1994). Magnesite presence is compatible with thermobarometry data for the locality Bečváry near Kolín: $845^{\circ} \mathrm{C}$ and $40.6 \mathrm{kbar}$ (Brueckner et al. 1991; Medaris et al. 2005).

\subsection{Absence of inclusions indicative of re-cycling of pre-Variscan peridotites with crustal history}

Although pyrope peridotites from several localities abroad carry mineral inclusions in pyrope, which are relics from a previous lower-temperature history, no such relics were found in Kolín pyrope. These relics pre-date formation of the orogenic belt in which the precursor peridotites were subducted to mantle depth. Brueckner and Medaris (2000) designated this group as IIAi class of prograde peridotites, and Zhang and Liou (1998) as type B garnet peridotites with a previous crustal history. Example from $\mathrm{Su}-\mathrm{Lu}$ terrane represents pyrope with abundant inclusions of chlorite, amphibole, Na-gedrite, talc, spinel and pyrite (Yang and Jahn 2000). The inclusion assemblage is interpreted as a record of crustal history preceding subduction by c. $220 \mathrm{Ma}$, which was accompanied by a high P-T equilibration corresponding to $1000^{\circ} \mathrm{C}$ and $\geq 5.1 \mathrm{GPa}$. In a similar way, some pyrope peridotites in the Caledonian belt in Norway contain evidence of an older crustal history (Brueckner and Medaris 2000).

\subsection{Causes of relative abundance of mineral inclusions in pyrope from the Kolín area}

The abundance of oriented acicular rutile in pyrope from the Kolín area, in contrast to their absence in samples from Podsedice and Vestřev, is inversely correlated with differences in $\mathrm{TiO}_{2}$ contents in the host pyrope. The fluctuations in the content of unmixed rutile probably indicate differences in thermal history of the garnet peridotites. Occurrences of acicular rutile in garnet are known in some high-P-T rocks such as granulites, eclogites and kimberlites (Dawson 1980; Chopin and Ferraris 2003; Zhang et al. 2003). The contrasting titanium behaviour in pyrope from peridotites in a single orogenic belt is a surprising aspect of pyrope occurrences in the Bohemian Massif.

The mineralogical and compositional differences in pyrope correlate with the geochronological ages of peridotites in the two areas: $377 \pm 20 \mathrm{Ma}$ (Brueckner et al. 1991; Sm-Nd method) for Bečváry location near Kolín (Fig. 2) and $342 \pm 5 \mathrm{Ma}$ (Gebauer 1991; U-Pb zircon dating) for T7 borehole at Staré near Podsedice. These results represent the first example of mineralogically documented differences between peridotites of the "palaeo-Variscan" and "neo-Variscan" age groups.

\section{Conclusions}

The quantitative chemical analyses of inclusions in pyrope from the Kolín area resulted in identification of the following minerals: rutile, magnesian ilmenite, olivine, enstatite, pargasite, phlogopite, barian phlogopite, spinel, magnesite and a probable crichtonite-group? mineral. Apatite, Ni-sulphide and chalcopyrite were identified qualitatively from WD spectra. The data obtained significantly expand the knowledge of accessory minerals in garnet peridotites in the Bohemian Massif, in which most of these minerals were previously unknown. Some of the mineral inclusions carry elevated abundances of trace elements and may even represent their important reservoirs, with implications for residence of trace elements in the garnet peridotites. The data obtained do not indicate the presence of re-cycled pre-Variscan peridotites with a crustal metamorphic history.

The mean $\mathrm{TiO}_{2}$ content in pyrope from the Kolín area is lower by $0.15 \mathrm{wt}$. \% than that in pyrope from Podsedice. This, together with the presence of unmixed acicular rutile in pyrope from the Kolín area, can be interpreted as a result of slow cooling, prolonged annealing, or repeated heating during the Variscan orogeny. This investigation illustrates the potential of comparative mineralogical studies to reveal the different properties and thermal histories of garnet peridotites in various tectonic units of the Bohemian Massif.

Acknowledgments. Pyrope samples were provided by $Z$. Běhal, who has been involved in collecting garnet in the Kolín area for a long time (Běhal et al. 2000; Běhal O. and Běhal Z. 2002). My thanks go to R. Čopjaková and $P$. Sulovský, Brno, for microprobe analyses conducted during joint sessions. My thanks are due to reviewers L.G. Medaris and M. Novák for their valuable suggestions and for correcting English. This study was done in the frame of an internal project of the Czech Geological Survey "Contrasting rocks in geological units at the NE border of the Moldanubian Zone", headed by J. Pertoldová. 


\section{References}

Aftalion M, Bowes DR, VRána S (1989) Early Carboniferous $\mathrm{U}-\mathrm{Pb}$ zircon age for garnetiferous perpotassic granulites, Blanský les Massif, Czechoslovakia. Neu Jb Mineral, Mh 1989, 145-152

Alberico A, Ferrando S, Ivaldi G, Sabau G (2003) Geikielite as microinclusion in Foltea (South Carpathians) pyropes. Abstracts of the $5^{\text {th }}$ EMU School on UHPM, Acta Mineral Petrogr 3: 3

Anczkiewicz R, Szcepanskij J, Mazur S, Storey C, Crowley Q, Villa IM, Thirlwall MF, JefFries TE (2007) Lu-Hf geochronology and trace element distribution in garnet: Implications for uplift and exhumation of ultra-high pressure granulites in the Sudetes, SW Poland. Lithos 95: $363-380$

BECKER H (1997) Sm-Nd garnet ages and cooling history of high-temperature garnet peridotite massifs and highpressure granulites from Lower Austria. Contrib Mineral Petrol 127: 224-236

BĚHAL O, BĚHAL Z (2002) Minerals accompanying pyrope in stream sediments south of Kolín. Minerál 10: 268-270 (in Czech)

Běhal Z, Novák F, Pauliš P, PejšA J (2000) Historical localities of Bohemian garnet (pyrope) in the Kolín area and their mineralogy. Práce muzea v Kolíně, řada př́rodovědná 4: 3-32 (in Czech)

Bobrov A, Litvin Yu, Kojitani H, Akaogi M (2007) Formation of Na-bearing majoritic garnets in the $\mathrm{Na}_{2} \mathrm{O}-\mathrm{MgO}$ $\mathrm{CaO}-\mathrm{Al}_{2} \mathrm{O}_{3}-\mathrm{SiO}_{2}$ system under extreme conditions of 7-24 GPa and 1500-2000 ${ }^{\circ} \mathrm{C}$. Geophys Res Abstracts 9: 3 pp

Brueckner HK, Medaris LG (2000) A general model for the intrusion and evolution of "mantle" garnet peridotites in high-pressure and ultra-high-pressure metamorphic terranes. J Metamorph Geol 18: 123-133

Brueckner HK, Medaris LG, BaKun-Czubarow N (1991) $\mathrm{Nd}$ and $\mathrm{Sr}$ age and isotope patterns from Variscan eclogites of the eastern Bohemian Massif. Neu Jb Mineral, Abh 163: 169-196

Chopin C, Ferraris G (2003) Mineral chemistry and mineral reactions in UHPM rocks. In: Carswell DA, Compagnoni R (eds) Ultrahigh Pressure Metamorphism. EMU Notes in Mineralogy 5, Eötvös Univ Press, Budapest, 191-227

Dallmeyer RD, Franke W, Weber K (eds) (1995) Pre-Permian Geology of Central and Eastern Europe. Springer Verlag, Berlin, pp 1-593

Dawson JB (1980) Kimberlites and Their Xenoliths. Minerals-Rocks-Inorganic Materials, No. 15, Springer Verlag, Berlin, pp 1-250

Deer WA, Howie RA, Zussman MA (1997) Rock-forming Minerals, Vol. 1A, Orthosilicates. Geol Soc, London, pp 1-919
DowTy E (1971) Crystal chemistry of titanian and zirconian garnet: I. Review and spectral studies. Amer Miner 56: 1983-2009

Enami M, Cong B, Yoshida T, Kawabe I (1995) A mechanism for $\mathrm{Na}$ incorporation in garnet - an example from garnet in orthogneiss from Su-Lu terrane, eastern China. Amer Miner 80: 475-482

Frost DJ, Boffa T, Langenhorst F (2004) High-temperature x-ray diffraction on the $\alpha \mathrm{PbO}_{2}$ structure of $\mathrm{TiO}_{2}$. Annual Report 2004, Bayer Forschungsinst Experiment Geochem Geoph, Univ Bayreuth, 48-49

GeBAuer D (1991) Two Palaeozoic high-pressure events in a garnet-peridotite of northern Bohemia, Czechoslovakia. Abstract 2nd Eclogite Field Symp. Granada. Terra Abstracts, (Suppl 6 to Terra Nova) 3: 5

HaGgerty SE (1991) Oxide mineralogy of the upper mantle. In: Lindsley DH (ed) Oxide Minerals: Petrologic and Magnetic Significance. Mineral Soc America Reviews in Mineralogy 25: 355-416

Hwang SL, Shen P, Chu HT, Yui TF (2000) Nanometer-size $\alpha-\mathrm{PbO}_{2}$-type $\mathrm{TiO}_{2}$ in garnet: a thermobarometer for ultrahigh-pressure metamorphism. Science 288: 321-324

HYRŠL J (2001) New gemmological study of large garnets of supposedly Czech origin. Z Dt Gemmol Ges 50: 37-42

HYRŠL J (2002) Gemmological study of so-called Kolín garnets and Bohemian garnets in the St. Vitus treasure. Minerál 10: 132-135 (in Czech)

JANOUŠEK V, ERBAN V, FARROW CM (2006) Interpretation of whole-rock geochemical data in igneous geochemistry: introducing Geochemical Data Toolkit (GCDkit). J Petrol 47: 1255-1259

Koutek J (1933) Geology of the crystalline area along the Sázava River. Věst Stát Geol úst 9: 319-353 (in Czech)

Kröner A, O’Brien PJ, Nemchin AA, Pidgeon RT (2000) Zircon ages for high pressure granulites from South Bohemia, Czech Republic, and their connection to Carboniferous high temperature processes. Contrib Mineral Petrol 138: 127-142

Kushiro I, Satake H, Акimoto S (1975) Carbonate-silicate reactions at high pressures and possible presence of dolomite and magnesite in the upper mantle. Earth Planet Sci Lett 28: 116-120

Leake BE, Wooley AR, Arps CES, Birch WD, Gilbert MC, Grice JD, Hawthorne FC, Kato A, Kisch HJ, KrivoviCheV VG, Linthout K, Laird J, Mandarino J, Maresch WV, Nickel EH, Rock NMS, Schumacher JC, Smith J C, Stephenson NCN, Whittaker EJW, Youzhi G (1997) Nomenclature of amphiboles: report of the Subcommittee on Amphiboles of the International Mineralogical Association Commission on New Minerals and Mineral Names. Mineral Mag 61: 295-321

Mazur S, Aleksandrowski P, Kryza R, Oberc-Dziedzic $\mathrm{T}$ (2006) The Variscan Orogen in Poland. Geol Quart 50: $89-118$ 
Medaris LG JR, Wang H, Jelínek E, Mihaljevič M, Jakeš $P(2005)$ Characteristics and origins of diverse Variscan peridotites in the Gföhl Nappe, Bohemian Massif, Czech Republic. Lithos 82: 1-23

Medaris LG Jr, BeARd BL, JeLíneK E (2006) Mantle-derived, UHP garnet pyroxenite and eclogite in the Moldanubian Gföhl Nappe, Bohemian Massif: a geochemical review, new P-T determinations, and tectonic interpretation. Int Geol Rev 48: 765-777

O'BRIEN PJ (2008) Challenges in high-pressure granulite metamorphism in the era of pseudosections: reaction textures, compositional zoning and tectonic interpretation with examples from the Bohemian Massif. J Metamorph Geol 26: 235-251

O`Brien P J, Kröner A, Jaeckel P, Hegner P, Żelaźniewicz A, Kryza R (1997) Petrological and isotopic studies on Palaeozoic high-pressure granulites, Góry Sowie Mts. Polish Sudetes. J Petrol 38: 433-456

Ř́ínošIl T, LANGrová A, KašPar P (1997) Gemmological study of pyrope from Podsedice and Vestřev. Sbor OMČR Turnov, 47-51 (in Czech)

Schmädicke E, Evans BW (1997) Garnet-bearing ultramafic rocks from the Erzgebirge, and their relation to other settings in the Bohemian Massif. Contrib Mineral Petrol 127: $57-74$

Seifert AV, VRÁna S (2005) Bohemian garnet. Bull Geosci 80: $113-124$

Sláma J, Košler J, Pedersen R (2007) Behaviour of zircon in high-grade metamorphic rocks: evidence from $\mathrm{Hf}$ isotopes, trace elements and textural studies. Contrib Mineral Petrol 154: 335-356

Sláma J, Košler J, Condon DJ, Crowley JL, Gerdes A, Hanchar JM, Horstwood MSA, Morris GA, Nasdala L, Norberg N, Schaltegger U, Schoene B, Tubrett MN, Whitehouse MJ (2008) Plešovice zircon - a new natural reference material for $\mathrm{U}-\mathrm{Pb}$ and $\mathrm{Hf}$ isotopic microanalysis. Chem Geol 249: 1-35

Sobolev NV, Lavrentyev YG (1971) Isomorphic sodium admixture in garnets formed at high pressures. Contrib Mineral Petrol 31: 1-12

Stachel T, Harris JW, Brey GP, Joswig W (2000) Kankan diamonds (Guinea) II: lower mantle inclusion paragenesis. Contrib Mineral Petrol 140: 16-27
Synek J, Oliveriová D (1993) Terrane character of the northeast margin of the Moldanubian Zone: the Kutná Hora Crystalline Complex, Bohemian Massif. Geol Rundsch 82: $566-582$

Vrána S, Blümel P, Petrakakis K (1995) Moldanubian Zone - Metamorphic evolution. In: Dallmeyer RD, Franke W, Weber K (eds) Pre-Permian Geology of Central and Eastern Europe. Springer Verlag, Berlin, pp 453-466

VRÁNA S, FRÝDA J (2003) Ultrahigh-pressure grossular-rich garnetite from the Moldanubian Zone, Czech Republic. Eur J Mineral 15: 43-54

Wang L, Essene EJ, Zhang Y (1999) Mineral inclusions in pyrope crystals from Garnet Ridge, Arrizona, USA: implications for processes in the upper mantle. Contrib Mineral Petrol 135, 164-178

Wendt J I, Kröner A, Fiala J, Todt W (1994) U-Pb zircon and Sm-Nd dating of Moldanubian HP/HT granulites from south Bohemia, Czech Republic. J Geol Soc, London 151: 83-90

Yang J, Godard G, Kienast JR, Lu Y, Sun J (1993) Ultrahigh-pressure (60 kbar) magnesite-bearing garnet peridotites from northeastern Jiangsu, China. J Geol 101: 541-554

YANG JJ, JAHN BM (2000) Deep subduction of Su-Lu garnet peridotites. Abstract, Internat Geol Congress Rio de Janeiro, 3 pp

ZHANG RY, Liou JG (1994) Significance of magnesite paragenesis in ultrahigh-pressure metamorphic rocks. Amer Miner 79: 397-400

Zhang RY, Liou JG (1998) Dual origin of garnet peridotites of Dabie-Sulu UHP terrane, eastern-central China. Episodes 21: 229-234

Zhang RY, Zhai SM, Fei YW, Liou JG (2003) Titanium solubility in coexisting garnet and clinopyroxene at very high pressure: the significance of exsolved rutile in garnet. Earth Planet Sci Lett 216: 591-601

ŽítT J, ŠŤastný M, Šrein V, Hradecká L (1999) Garnet and some other minerals in the shallow-water deposits of the Kutná Hora-Karlov locality (Bohemian Cretaceous Basin, Czech Republic). Bull Czech Geol Surv 74: $279-288$ 


\section{Minerální inkluze v pyropu z granátických peridotitů v okolí Kolína, Česká republika}

Inkluze minerálů v pyropu jsme studovali s důrazem na častou přítomnost orientovaných krystalů jehlicovitého rutilu. Pyropy z okolí Kolína jsou v tomto ohledu odlišné od pyropů ze dvou těžených lokalit, t.j. Podsedic a Vestřevi u Trutnova. Cílem práce bylo získat také informace o inkluzích jiných minerálů, jejichž př́ítomnost indikovalo dřívější gemologické studium. Kvantitativní analýzy vzorků pyropu získané z kvartérních sedimentů u Kolína svědčí o určité variabilitě chemismu: Prp 67,9-71,6 mol. \%, Alm 13,3-18,9, Grs 2,0-7,5, Uvr 2,6-9,6. Analýzy pomocí elektronové mikrosondy prokázaly př́ítomnost těchto minerálů v podobě inkluzí v pyropu: rutil, hořečnatý ilmenit, olivín, magnesit, enstatit, pargasit, flogopit, barnatý flogopit, spinel, a minerál pravděpodobně ze série crichtonitu. Apatit, Ni-sulfid a chalkopyrit byly určeny na základě kvalitativních spekter. Publikovaná stáří Sm-Nd indikují dvě věkové skupiny granátických peridotitů v Českém masivu, „neovariskou“ ( 339 Ma) a „paleovariskou“ (370-377 Ma). V okolí Kolína bylo datováno těleso u Bečvár na $377 \pm 20$ Ma. Vyvstává proto otázka, zda „paleovariské“ granátické peridotity v okolí Kolína obsahují nějaký mineralogický záznam dlouhodobějšího prohřívání, nebo opakovaného zahřívání, které se mohlo vyskytnout v časovém intervalu mezi dvěma uvedenými geotektonickými událostmi. Na druhé straně, získaná data o inkluzích nepodporují možnost, že by peridotity v okolí Kolína mohly představovat starší recyklované peridotity s předvariskou krustální historií. Průměrný obsah $\mathrm{TiO}_{2}$ v pyropech z okolí Kolína ( 0,37 hm. \%) se odlišuje od hodnoty $0,46 \mathrm{hm}$. $\% \mathrm{TiO}_{2}$ pro pyropy z Vestřevi a $0,52 \mathrm{hm}$. \% $\mathrm{TiO}_{2}$ pro pyropy z Podsedic. Je pravděpodobné, že poměrně nízký obsah Ti v pyropech od Kolína může být důsledkem částečného odmíšení Ti v podobě jehlicovitých krystalů rutilu. Získaná data indikují zajímavé možnosti srovnávacího mineralogického studia peridotitů v dílčích jednotkách Českého masivu. 